University for Business and Technology in Kosovo

UBT Knowledge Center

UBT International Conference

2018 UBT International Conference

Oct 27th, 3:15 PM - 4:45 PM

\title{
Contemporary trends in banking
}

\author{
Bashkim Nuredini \\ University for Business and Technology, bashkim.nuredini@ubt-uni.net \\ Muhamet Gërvalla \\ University for Business and Technology, muhamet.gervalla@ubt-uni.net
}

Follow this and additional works at: https://knowledgecenter.ubt-uni.net/conference

Part of the Business Commons

\section{Recommended Citation}

Nuredini, Bashkim and Gërvalla, Muhamet, "Contemporary trends in banking" (2018). UBT International Conference. 285.

https://knowledgecenter.ubt-uni.net/conference/2018/all-events/285

This Event is brought to you for free and open access by the Publication and Journals at UBT Knowledge Center. It has been accepted for inclusion in UBT International Conference by an authorized administrator of UBT Knowledge Center. For more information, please contact knowledge.center@ubt-uni.net. 


\title{
Contemporary trends in banking
}

\author{
Bashkim Nuredini ${ }^{1}$, Muhamet Gërvalla ${ }^{2}$
}

\author{
${ }^{1,2}$ University for Business and Technology UBT, 10000 Prishtinë, Kosovo \\ bashkim.nuredini@ubt-uni.net; muhamet.gervalla@ubt-uni.net.
}

\begin{abstract}
Over recent decades, serious changes occurred in the economic, technological and social development, having reflected on banking operations. Changes ensuing today in the field of banking are of utmost significance. Banks are becoming multifunctional or in a certain fashion, are becoming genuine department stores of the modern age. The globalization of financial and banking flows is realized by conceiving a new banking concept, due to bank adjustment to the new conditions of management.

The traditional bank role has been evidently altered, hence banks in presentday conditions, apart from the standard banking operations, conduct a major number of unconventional banking operations, for instance, operations with securities, bank guarantees, mortgage services etc. Modern banks offer their clients a wide range of services, thus aggressively entering certain non-banking areas, by which they transform themselves into universal financial institutions. In the modern world banking system, we encounter banking and financial institutions which according to their activities and prevalence in their operations exceed national borders and enter the domain of the international banking system. Nowadays, we can discuss about alleged planetary banking with engineering and re-engineering. It is characterized by its sophisticated, processing and globalized banking features. In a short time interval, within the international banking system, several large-scope changes occurred, revolutionary in its essence, not solely in terms of banking, as well as in terms of the total monetaryfinancial-banking system. The determinants of such changes are as follows: altered conditions of fierce competition and fight to remain on the financial market; an electronic and technological revolution which resulted in the substitution of banking products with production of segmented banking process; and creation of new planetary banks which place their segmented banking processes on the so-called globalized supranational market.
\end{abstract}

Keywords: international banking, deregulation, competition, globalisation, ebanking. 


\section{$1 \quad$ Introduction}

Over the past decades, there have been serious changes in the economic, technological and social development, which have affected banking operations. Changes that are happening today in the banking sector are of great importance. Banks are becoming multifunctional, or they, in a way become real department stores of modern times.

The traditional role of the banks has been visibly changed, so that now, in addition to standard operations, they perform a number of untraditional banking operations, such as operations with securities, guarantees, mortgage services etc.

Seen through the prism of their development, banks, over a long period of time dealt with several standard operations: they mediated in payments, they collected deposits from the population and legal entities, and they approved loans. At today's level of development of commercial banking, these traditional activities are complemented with new ones.

The most important additional activity of the commercial banks today is the activity of the financial markets. Commercial banks get funds also through emission of bonds and other securities. Also, in the policy of placements, in addition to standard loan placements, commercial banks are increasingly placing free funds in the purchase of various securities.

Today's banks offer to their clients a number of services and thus aggressively enter some nonbanking areas and transform into universal financial institutions. In the banking of the modern world, we encounter banking and financial institutions, which according to their activities and their prevalence in their activities, cross the national borders and enter the field of international banking.

These are banks that are not international or regional banking and financial institutions in their essence, but by their activity, although they are registered as so-called national banks, banks of the national economy, they are, however, more than national banks, because their operations are increasingly involved in the international monetary, financial and credit relations and trends. These banking and credit institutions along with the international and regional financial and banking institutions form the so-called international banking.

Hence, the issue of analyzing the trends in international banking arises. If we analyze the development of the international banking in the so-called financially developed countries from an institutional, organizational and functional aspect, we realize that this development has been characterized with the existence of standard (traditional), that is to say, conservative service banking ever since the beginning. Later on, it switches to industrial production banking.

Today we can talk about so-called planetary banking with engineering and reengineering. International banking or as some call it planetary banking started to develop in the nineties of the 20th century. In a short period of time, several major changes happened within the international banking, which was revolutionary in essence, not only for the banking but also for the total monetary-financial banking system. 
Determinants of these changes are: the changed conditions of the tough competition and the struggle to survive on the financial market; the electronic-technological revolution that caused replacement of the production of a bank product with the production of a market segmented banking process; and creating new planetary banks that place their segmented banking processes on a so-called globalized supranational market.

The efficient functioning of the banks depends on their flexibility, i.e. their ability to adapt to changes that would provide a competitive advantage compared to other financial institutions.

\subsection{Competition among banking institutions}

One of the most important fundamental factors in the transforming of traditional commercial banks into modern universal institutions is the competition. The competition is a driving factor in the growing trends in the global economy. Increased competition forces banks to take risky activities to make adequate acceptable profits. The increased rivalry among the bank institutions is manifested in two forms:

- price competition causes more favorable interest rates for the clients of the banks;

- production competition causes expansion of bank products and services in order to meet the needs of the clients of the banks. Under the pressure from the competition, banks create new services with improved quality.

- In conditions of increased competition, however, commercial banks undertake several steps, as follows:

- make greater use of the securitization of loans;

- provide guarantees, support the liquidity of other institutions, loan, credit enhancements and they support a number of different instruments on the financial market;

- strengthen the activity of the securities market through their emission, brokerage, and activities of joint funds. For banks to face the competition, they must adapt to the new environment, and also find new products/services. All this affects the increase of the competition in different spheres: competition for deposits, competition for loans, competition for payment services and other banking services.

\subsection{Competition for deposits}

This type of competition has a wide scope. To be precise, first of all, commercial banks can offer different products/services under different conditions (depending on the maturity, interest rates and amount of investments).

\subsection{Competition for loans}

Lately, the competition for loans has increased. The development of junk bonds (bonds with suspicious quality or junk bonds) contributes to this. These bonds are a successful substitute for loans. In order to seek loans from banks, business entities 
(with a lower rating) start collecting additional funds by issuing junk bonds. All these activities contributed the banks to focus on competition in the credit activities area.

\subsection{Competition for payment services}

With the emergence of the electronic payment systems, competition among banking institutions and competition in payment services has increased.

\section{Regulation and Deregulation of Banking}

Compared to other institutions, banks are convincingly the most regulated institutions in the economy. The main reasons why regulatory bodies in every country are constantly striving to regulate banking activities are different. But, mainly, two basic motives can be distinguished. The motive of the first one is the security of the banks, whereas the other one is concerned with monetary and tax policy (usually managed by the Central Bank. The regulation of banking derives from four different historical roots:

1. The special conditions of the credit institutions established by order of the ruler of the state, usually to facilitate state borrowing;

2. The system of concessions regulating the founding of banks with their limited authority;

3. Control of the issuing of bills that have acquired the character of money;

4. The belief that the general supervision of the credit system is a prerequisite for unimpeded functioning of the banking system.

The increased globalization of the global financial trends and the increase of the international banking activities impose the need for an international regulatory and supervisory framework, which will be presented below in the area of the international banking standardization.

In general, the main objectives of banking regulation can be summarized as follows:

1. Providing a stable banking system, in order to increase public confidence, especially of small savers, who are not able to independently estimate the risk of the banks and the security of their deposits in them;

2. Preventing irresponsible behavior of banks by excessive risk-taking;

3. Securing the clients and securing the regularity of the financial market;

4. Protecting the bank, that is to say, their owners from the bad decisions of the banking management.

\subsection{Deregulation}

The beginning of the $21^{\text {st }}$ century was marked by the process of globalization, which like a fire spread on the planet Earth and had a direct impact on the economic 
and social movements. After the oil shock in the 1980s, changes occurred in the economic science and theory. Economists who represent the ideas of the Neo-liberalism enter the arena and ask for reassessment and harmonization of the role of the individual, the state's neutrality on economic life and the rule of law. One of the leading neoliberal followers, Peter Drucker, of the changes that occurred during the 1970s, said: „From the perspective of the oil shock and the decision of President Nixon to allow floating exchange rate of the dollar, it can only be regarded as the beginning of the events. Under the influence of this direction in the economy, in the highly developed countries, destatization of the state enterprises and radical deregulation is carried out. Since the late 1970s, a global trend of deregulation is present, a term that marks the process of removing existing legal regulations that limit the operation of banks.

Historically, the process of deregulation of banking services started in the early 1970s in New England and spread across all of the United States, and later in some Western European countries. The first comprehensive deregulation act was adopted in 1980. The Depository Institutions Deregulation and Monetary Control Act and the big structural deregulation in the USA happened with the repeal of the Glass-Steagall Act in 1999, through the Gramm-Leach-Biley Act. With these legal reforms in the USA, it was allowed to establish holding companies for financial services that can deal with commercial and investment banking, as well as with insurance services. First of all, the deregulation process means removal of regulations that limit the services the banks can offer. By accepting the concept of deregulation by the most developed countries in the world, a room was given for competition among the different financial institutions. As a result of this process banks gradually equated with the other financial institutions. The deregulation and the growing competition caused a reduction in interest rates, which had a negative impact on the profitability of the banks.

The growing tendency towards the global operations of banks on world markets has contributed to the revoking of the separation of commercial and investment banking. In addition to the increased liberalization of financial operations, an increase in the capital flow and entry of foreign financial institutions on the domestic markets, occur. The universal bank becomes a prevalent model. Apart from dealing with savings and deposit operations, it also dealt with investment-brokerage operations. Deregulation processes have led to significant changes in the place and role of commercial banks in the banking environment, with huge consequences in the existing and future functioning of banks. The latest financial crisis has called into question the broad deregulation in the banking area. Today, after that phase of general deregulation, which has long been a priority of the state, there is a new phase ahead, based on the need for efficient financial and legal supervision, in order to early detect problems that could lead to a financial crisis of large scale. In fact, strict regulatory rules are introduced, aimed at supervision of the financial sector. 


\section{Introduction of technological innovations in banking}

Information technology has had a great impact on the operations of banks. The use of increasingly advanced technology in banking operations has caused integration trends both nationally and internationally.

The modern information-communications technology has caused a technological revolution among banks. With the help of the electronic devices, banks have established an interactive connection with their clients, and thus reduced the costs of their transactions. Electronic banking includes systems that enable users of banking services, natural or legal to have access to them, to make specific transactions, or to get information about financial products and services through a public or private network, including the Internet. Paper-based payment instruments are increasingly reduced, and analogous to these traditional payment instruments, new instruments for electronic payment have been developed, among which, most commonly used are: the electronic cash, electronic check, and payment cards.

E-banking means a technique for performing banking operations or a manner of delivering bank products and services. Basel Committee on Banking Supervision (BCBS) defines the term e-banking as "distribution of banking services and products in a new way, through electronic channels".

These banking services and products include bank deposits and loans, accounting management, as well as providing other products and services (for example e-cash) for electronic payment. The term e-banking is often equated with the term online banking. However, this is wrong because the term e-banking is a wider concept and includes other ways of performing banking transactions via devices that are not based on internet-technology. E-banking includes systems that allow users of banking services, natural or legal, to have access to them, to make certain transactions or to obtain information about financial products and services through a public or private network, including the Internet.

The users of the services offered by e-banking access them by using modern electronic devices, such as personal computer (PC), personal digital assistant (PDA), cash machine (ATM) etc.

\subsection{Types of e-banking}

The development of technology and innovation has contributed to changes in the way of communication between the clients and the bank, i.e. the execution of electronic services in a new way, more perfect than the previous one. From this aspect, several types of e-banking are distinguished, i.e. home banking over the telephone, Intranet network, Internet network and mobile phone.

Home banking is a system for using banking services directly from the home of the client and offers the possibility of establishing a telecommunication link with the computer center of the bank in order to use the banking services. As a link to the computer center of the bank, the client uses a telephone, TV or a computer. In the process of developing home banking, we distinguish three phases, depending on the type of telecommunication link between the bank and the client: 
- Telephone banking

- Online banking (home banking based on Intranet)

- Internet banking

- Mobile banking

- ATM devices (cash-machines)

- ATM Network

- POS - systems

- Electronic payment systems

The first appearance of telephone banking was noticed in the 1970s. It is a process of using banking services directly from the client's home and enables the immediate transfer of funds, orders and information through the telephone network. There are two ways to perform these operations, depending on the manner of establishing a connection by the client with the bank officer or with the computer center of the bank.

In the first way, the client should only contact a bank officer, and through them, the operations of the bank computer are carried out.

In the second way, the client should have a phone with a special magnetic tape reader or a special keyboard on which the client independently enters data that are needed to enter the banking system. For the use of banking services, the client needs to have their own account in the bank, to have a telephone line and possibly a token.

Online banking - online banking is making banking transactions between the client and the bank via a direct computer connection, using special software installed on the personal computer of the client. The communication between the client (through their computer) and the banking computer center is carried out through a closed network communication system of the bank - intranet, using a modem. All data of the executed orders are available to the user through the software installed on their computer.

Internet banking - natural successor of the online banking is the internet banking. The use of the telephone lines and TVs to access the bank and their services have been significantly reduced, and the use of the Internet for this purpose is on the increase, so today the term home banking can be freely replaced with the term internet banking. Internet banking and its beginning in the true sense were noticed in 1995 when the bank Wells Fargo 7 made the first banking web program to perform banking operations through the Internet. The same year, the first specialized internet bank in the world, Security First Network Bank, was founded, based in Atlanta, the USA, and later other banks were founded, such as Compubank, Wingspanbank etc.

Mobile banking - the latest trend in the development of electronic banking is mobile banking. It allows simple and practical use of the banking services anytime and anywhere via a portable computer (laptop, netbook, tablet, pc), PDA, smart phone or mobile phone. The latest generation of mobile phones allows connecting to the Internet directly from the phone, which means that the user can access the bank through it and make banking transactions. Its biggest advantage is that the mobility, that is, the services provided by mobile banking are independent of the location of the users and the operator, and thus banking services are available 24 hours, 365 days from anyplace in the world covered by GSM signal. 
ATM devices (cash-machines) - the Automated Teller Machines, or the so-called cash machine (ATM), is an automated device, usually installed outside the bank or in certain busy locations, whose main role is to provide certain financial services to its users, without the presence of a bank official.

ATM Network - in the first years of the introduction of the ATM, having a network of cash machines meant that the bank had a prestige. Today, cash machines are connected in a network, so the users can use the card issued by one bank to withdraw money from a cash machine of another bank by paying a commission. From a perspective of increasing the economy in the operation of banks, the practice has shown that the increased use of ATM devices does not necessarily mean more profitable execution of transactions because often customers use them to withdraw small amounts.

POS - systems - The point of sale is a payment system that enables the fast realization of financial services in the commercial and service network through e-banking.

Electronic payment systems - electronic payment systems can be said to be one of the most important links in the chain of participants in the financial system in a country. They must be practical for online shopping, secure and safe, transferable across networks and cost-effective for small transactions. Today, electronic payment systems can be divided into the following four groups:

- electronic money payment systems;

- payment card payment systems;

- electronic micro-payment systems (accumulated balance);

- e-check payment system.

In addition to these payment instruments, the following instruments can also be used for online payment:

- online payment systems with stored values (PayPal, Smart cards)

- e-wallet.

\section{Conclusion}

The banking system has undergone significant changes over the past two decades in which banks have transformed their activities from relatively closely defined activities, to becoming financial enterprises that offer the full range of services. Traditionally, the main activity of the banks consisted of accepting deposits and granting loans, with the largest portion of their incomes being realized from granting loans

Until 1990, numerous banking markets were highly regulated, and on the other hand, the competition was limited. In this regard, in the UK, banks were banned from dealing with various banking activities related to securities and investments until 1986, when through various reforms commercial banks were allowed to buy companies that operate as brokers with shares.

On the other hand, in continental Europe until 1992, in Spain and Italy, the restrictions on the opening of representative offices were in force, and the banks were 
limited in terms of the types of operations they were able to deal with. With the application of the Second EU Banking Directive of 1998, in 1992, a formal definition of what constitutes banking operations across Europe was established. The transformation of the banking system over the last two decades was aimed at creating an efficient and reliable banking sector.

This was an overture by which the model of so-called universal banking was introduced. According to the broad definition, the model of universal banking includes all aspects of the activity with financial services, including security, insurance, pensions, leasing, etc.

The role of the state-owned banks in Europe and elsewhere declined as a result of the privatization process, and various constraints that existed in the past with the balance sheet (known as portfolio constraints) were reduced or canceled, by which the banks were given greater freedom in the financial management of their activities.

These global trends were complemented by the advances in technology, which revolutionized the office processing and the on-premise delivery of financial services to customers. General improvements in the communication technology and lower communication costs have increased the role of the rival powers, as physically remote financial service providers are becoming more relevant to their competitors. Technology has continued to blur the boundaries of specialization among financial intermediaries. So, technological booms have generally facilitated the growth of available financial services and raised the level of the competitive environment

Today banks are considered financial enterprises that offer complete services and it should be emphasized that certain banks have deleted the word bank from their name in the promotional materials, such as Berkeley in the UK and J.P. Morgan Chase in the United States. The motive to transform banks into financial institutions that offer complete services was the strategic goal of the banks in order to meet the broadest possible range of customer requirements for financial services.

\section{References}

1. Banking Act 1933.

2. Barbara Casu, Claudia Giradone, Philip Molyneux, Introduction to banking, Harlow, Essex: Financial Times Prentice Hall, 2006.

3. Block Stanley B., Hirt Geoffrey A., Основи на финансиски менаџмент, McGraw-Hill Irwin, Глобал Комуникации, Скопје, 2008 година.

4. Corton Gary, "bank regulation when 'banks' and 'banking' are not the same", Oxford review of economic policy, vol 10, no 4.)

5. Drucker, F.P., Nova zbilja, Novi Liber, Zagreb,, 1992.

6. Electronic Banking Services - Брошура.

7. Friedman, T., The Lexus and Olive Tree, Understanding globalization, Farar Starus Giroux, New York, 1999, стр.7-8.

8. Globalization and Liberalizatio, Development the Face of Two Powerful Currants, UNCTAD/366/Rei 1, 1996, p.5.)

9. Palan, R.and Deang, P." Safes Strategies in the Global Political Economy", in Paperback, C.I.P.G.INC,1996. 
10. Škrbić Milan Deskar, Istraživački rad "Deregulacija i monetarna politika FED-a kao uzroci globalne finansiske krize", Zagreb, listopad 2009 godina.

11. Walters, Malcolm.Globalization...pp. 21-21.

12. Јовановски Тихомир, Меѓународни финансии, Еуро-Мак Компани д.о.о, Скопје, 2007 година, стр.97.

13. Попоска Климентина: Комерцијално банкарство-успешност и профитабилност, Економски институт-Скопје, Скопје, 2008, година.

14. Ристиќ Живота "Светско банкарство-вчера, денес и утре" Економски факултет во Скопје, 1996 година.

15. Cohen Edward E., Athenian Economy and Society: A Banking Perspective, Princeton University Press, 1992.

16. Heffernan, S. (2005). Modern Banking. John Wiley and Sons Ltd.

17. J. P. Morgan. (1997). Introduction to Credit Metrics. J. P. Morgan \& Co. Incorporated

18. Kane, E. J. (2009). Incentive Roots of the Securitzation Crisis and the Early Mismanagement. Yale Journal on Regulation 26 (2), 405-416. 